\title{
The Effect of Celebrity Endorser Perceived Credibility and Country of Origin Image towards Purchase Intention of Skechers Apparel in Indonesia
}

\author{
Muhammad Bryant Muhadzdzib Abiyyu ${ }^{1}$, Nurrani Kusumawati ${ }^{2}$ \\ \{muhammad_bryant@sbm-itb.ac.id ${ }^{1}$ \} \\ Institut Teknologi Bandung, Indonesia ${ }^{1,2}$
}

\begin{abstract}
As the global competition is intensifying, the strategy implemented by producers and retailers should be pertained globally to achieve the purchase intention of customers. Purchase intention can be made by using country of origin strategy and celebrity who was employed to be endorsers of a brand. Skechers is a brand that originated from United States, which is known as one of the centers of fashion, and they collaborate with well-known celebrities to promote their products in Indonesia. The purpose of this paper is to investigate the effect of country of origin image and three dimensions of celebrity endorser credibility (attractiveness, trustworthiness, and expertise) towards purchase intention of Skechers apparel in Indonesia from the customers perspective. Quantitative research design with survey method was employed in collecting the data from 214 desired respondents who have been chosen by using purposive sampling technique with some criteria. Then, researchers use multiple regression analysis to test the hypotheses. The result indicates that country of origin images and all three dimensions of celebrity endorser perceived credibility significantly influence the purchase intention. Furthermore, country of origin image, celebrity perceived trustworthiness, and celebrity perceived expertise give positive effect on purchase intention. However, the impact of celebrity perceived attractiveness on purchase intention delivers a negative impact. Therefore, researchers suggested that Sketchers management in Indonesia should utilize the Sketchers country of origin, which is United States in their marketing communication strategy, as well as celebrity perceived trustworthiness and expertise of their endorsers since these potentially increase customer purchase intention.
\end{abstract}

Keywords: Country of Origin Image, Celebrity Endorser Perceived Credibility, Purchase Intention, Quantitative, Multiple Regression Analysis.

\section{Introduction}

As the global competition is intensifying, all companies need to develop a marketing orientation which is international in nature [1]. The main objective of the companies is to get high profit or high sales [2]. High sales or profit can be achieved by companies when the extent of purchase intention of the customer is also high.

One approach that retailers can do is to use the concept of $\mathrm{COO}$ or Country of Origin [3]. In Indonesia, Country-of-origin is seemingly one of the influencing factors in the purchase decision. According to Ali Charisma, Chairperson of the Indonesia Fashion Chamber (IFC) in CNBC Indonesia, "60\% of (Indonesian) consumers are still pursuing 
foreign brands because I admit (that) their quality is good and the prices are affordable". Furthermore, according to Badan Pusat Statistik (BPS), one of the biggest imported products are sneakers.

Skechers is a brand that is running in footwear industry that is based in Manhattan Beach, California. They design, develop, and provide more than 3000 shoe styles for men, women, and kids. Skechers is a brand that originated from United States which is known as one of the centers of fashion.

They are running in the sportswear industry that is acknowledged as the specialized industry from America. As stated by Benatti [4], sportswear is recognized as the specialization of the United States, where this type of apparel requires a lot of technology and it fits the United States country well because in terms of culture it is a very sporty country.

Whilst, the best-selling shoe brands in Indonesia in 2018 according to APRISINDO, Adidas was ranked first with a demand of 98,902 units, followed by Nike with 96.481 units, Reebok with 41.362 units, New Balance with 25.215 units, and Under Armour with 34.721 units. From here, the sneakers market share holders in Indonesia are still dominated by overseas brands.

However, Skechers was not included in the top 5 best-selling shoe brands in Indonesia. This indicates that Skechers has not been dominating the market share in Indonesia, even though Skechers originated from United States that is known as one of the centers of fashion and specialized in sportswear. Therefore, Skechers needs to assure the effect of their $\mathrm{COO}$ to the purchase intention of Indonesian consumers.

In marketing their products, Skechers also collaborates with well-known celebrities to promote their products. According to their website, seven notable figures are currently ambassadors of Skechers for the lifestyle division collection including platinum awardwinning singer Camila Cabello. This strategy intends none other than to influence consumers to purchase their products. Advertisers assume that by using celebrities will make the consumers respond positively towards the products featuring celebrities and it is worth the money [5].

Furthermore, from the previous events, celebrity endorsements became effective when the sports brands collaborated with sports celebrities, such as Michael Jordan with Nike and Messi with Adidas. The impact of symbolic communication can be maximized preferably between consumer and product when there is compatibility between characteristics of the endorser and the product [6]. Therefore, Skechers needs to understand the effect of using a singer celebrity endorser in their marketing strategy towards purchase intention of Indonesian customers since the background of the celebrity is not related with brand's nature.

Consequently, researchers wanted to study about 3 issues of Skechers in Indonesia, namely Country-of-origin Image, Celebrity endorsement perceived credibility, and Purchase Intention. Hence, research questions can be defined as follows:

1) How is the effect of Country-of-Origin towards Purchase Intention of Skechers sportswear apparel?

2) How is the effect of Celebrity perceived credibility towards purchase intention of Skechers sportswear apparel? 


\section{Theoretical Foundation}

\subsection{Country of Origin Image}

Country-of-origin image is defined as the image of the country that consumers are associated with a particular brand or product as its origin regardless of the place or manufacture [7]. For instance, the products of Nike brand are manufactured in many countries but customers are still considering America as the Country of origin [8].

The main advantage of a strong Country of origin of a product is that it serves as aclue of product quality and influences the tendency of purchase immediately [9]. Country of origin image does play a very important role when a consumer makes a purchase decision [10].

The study undertaken by Hien et al. [11] revealed that Country-of-origin is determined as a significant information in evaluating the brand of the product, specifically in influencing customer's purchase intention which indicates that COO plays an essential role in the purchase decision's process. This study supports Hanzaee and Khosrozadeh [10] who indicated that $\mathrm{COO}$ image has a significant effect on purchase intention of consumers. Moreover, Kim et al. [8] explained that astronger country of origin image of fashion collection will result in higher purchase intention of consumers.

\subsection{Celebrity Perceived Credibility}

Based on Ohanian [12], three global characteristics can make a celebrity more effective, namely: attractiveness; expertise; and trustworthiness. Furthermore, The source-credibility model indicates that the efficiency of the message communicated by an endorser relies on perception of the consumers towards brand endorser's expertise, trustworthiness, and attractiveness [13][14]

According to Ketchen et al. [15], Trustworthiness indicates to the extent in which a celebrity, while transferring a message of honesty, integrity, and believability through advertising, is perceived by customers. Trustworthiness refers to the message audience's degree of confidence in, and the level of acceptance of, the endorser and the message [12].

Expertise is defined as the compatibility between the celebrity endorser and the product so that a celebrity endorser can have special knowledge or experience with the category to have special expertise [16]. Whilst, Attractiveness involves outward physical appearance of someone, that is, someone who is considered as beautiful, elegant, or classy [13][17][18].

The study done by Pornpitakpan [5] indicated that those three celebrity credibility dimensions influence the purchase intention of Singaporean, where they seem to give more weight to the celebrities' attractiveness and trustworthiness.

The study of Osei-Frimpong, Donkor, and Owusu-Frimpong [19] also suggested that the endorser's characteristics that include the level of familiarity, attractiveness, and trustworthiness on consumers' perception influence their purchase intention. Additionally, Ohanian [12] discovered that celebrity endorsers' perceived expertise explained significantly the purchase intention of the subject on the product.

\subsection{Purchase Intention}

Purchase intentions reveal consumers' predicted or planned future behaviors, or the chance that behavior and belief will be translated into behavior of buying [20]. Consumer purchase intention refers to the "possibility of consumers' willingness of purchasing some specific products" [21]. 


\subsection{Hypotheses}

Based on the explanation above, the hypotheses can be defined as follows:

H1. There is a significant relationship between country-of-origin towards purchase intention of Skechers brand in Indonesia.

H2a. There is a significant relationship between Celebrity Endorser's Perceived Attractiveness towards Purchase Intention of Skechers brand in Indonesia.

H2b. There is a significant relationship between Celebrity Endorser's Perceived Trustworthiness towards Purchase Intention of Skechers brand in Indonesia.

H2c. There is a significant relationship between Celebrity Endorser's Perceived Expertise towards Purchase Intention of Skechers brand in Indonesia.

\subsection{Conceptual Framework}

Consequently, based on the previous studies and hypotheses, the new conceptual framework can be built as follows:

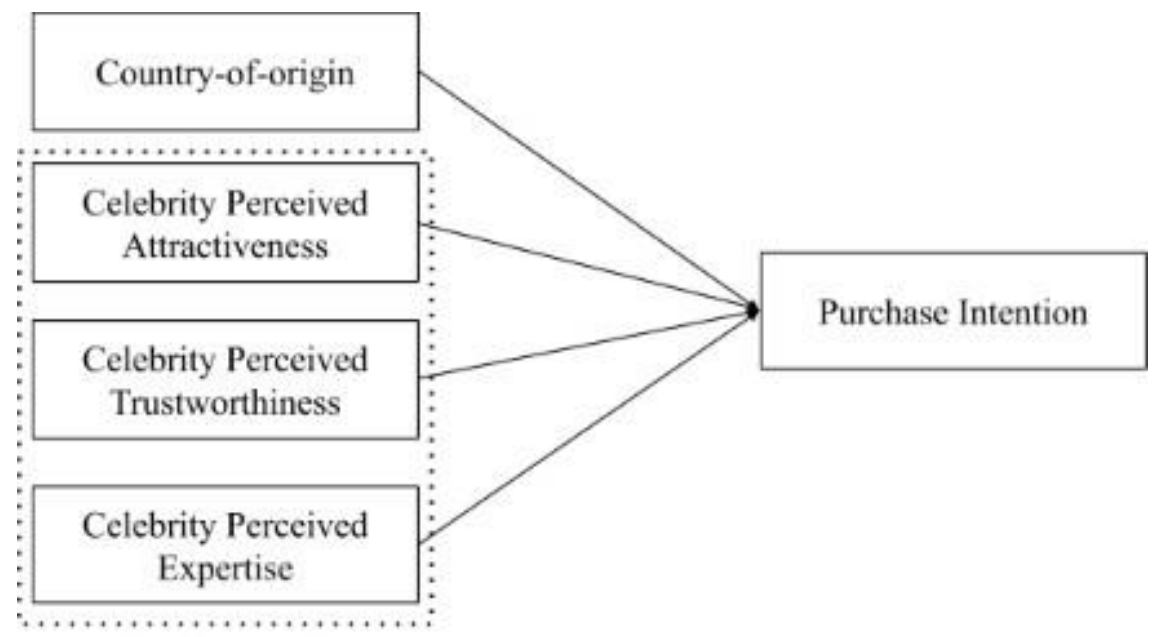

Celebrity Perceived

Credibility

Fig. 1. Conceptual Framework

\section{Research Methods}

\subsection{Types of Research}

This research is categorized as quantitative research in terms of data collection technique. The data collection technique used was survey as the method of collecting data. This research is classified into causal associative research which is a study by looking for a relationship or effect of cause and effect, namely the relationship or influence of the independent variable (X) on the dependent variable (Y) [22]. The type of survey method was questionnaire, where it is defined as a data collection technique that is done by giving a set of questions or written statements to respondents to be answered [22]. 


\subsection{Operational Variable}

There are 2 kinds of variables in this study, namely: Independent variables (country of origin image and celebrity perceived credibility) and Dependent variable (purchase intention. All indicators of questions of each variable is derived from previous studies. According to Hien et al. [11], country of origin image consists of 7 indicators and purchase intention consists of 5 indicators. Whilst, based on Pornpitakpan [5], celebrity perceived trustworthiness, celebrity perceived attractiveness, and celebrity perceived expertise consists of 3 indicators each. For the subject of celebrity perceived credibility, Camila Cabello was selected. For the scaling method, Likert scale method was employed by using 5 categories ( $1=$ "strongly disagree", $2=$ "Disagree", $3=$ "Undecided", 4= "Agree", and 5= "strongly agree").

\subsection{Population and Sample}

Researchers used a non-probability sampling method. The type of non-probability sampling used is purposive sampling technique. The criteria of the respondents of this study, namely: Know the Skechers brand; Know about the singer Camila Cabello who is a brand endorser from Skechers; Live in Indonesia, focusing on Jakarta, Bandung, Medan, Yogyakarta, and Surabaya since these areas before and these areas have the highest number of Skechers stores. According to Hair [23], the number of samples is the number of questionnaire indicators multiplied by 10 . Therefore, the minimum sample in this study is 210 samples.

\subsection{Data Analysis}

Since, this research intends to explain the influence of country of origin image, celebrity perceived attractiveness, celebrity perceived trustworthiness, and celebrity perceived expertise on purchase intention of Skechers, hence Researchers used multiple regression analysis. Regression analysis is used to see how the influence that exists between the independent variables on the dependent variable [24]. The data is processed statistically to analyze and test the hypotheses using SPSS 23.0. The multiple regression method is formulated as follows:

\begin{tabular}{|c|c|}
\hline $\mathbf{Y}$ & $=a+\beta 1 X 1+\beta 2 X 2+\beta 3 X 3+\beta 4 X 4+\epsilon$ \\
\hline Y & $=$ Purchase intention \\
\hline $\mathrm{X} 1$ & $=$ Country of origin image \\
\hline $\mathrm{X} 2$ & $=$ Celebrity perceived attractiveness \\
\hline $\mathrm{X} 3$ & $=$ Celebrity perceived trustworthiness \\
\hline $\mathrm{X} 4$ & $=$ Celebrity perceived expertise \\
\hline$\beta 1, \beta 2, \beta 3, \beta 4$ & $=$ Regression Coefficient \\
\hline a & $=$ Constanta \\
\hline $\mathrm{e}$ & $=$ Standard Error \\
\hline
\end{tabular}

\section{Results and Discussion}

\subsection{Validity and Reliability Test}

Table 1. Validity Test Results

\begin{tabular}{ccccc}
\hline Variables & Indicators & r statistics & Significance & Conclusion \\
\hline & XA1 & 0.804 & 0.000 & Valid \\
& XA2 & 0.653 & 0.000 & Valid \\
\hline
\end{tabular}




\begin{tabular}{lcccc}
\hline COOI & XA3 & 0.716 & 0.000 & Valid \\
& XA4 & 0.792 & 0.000 & Valid \\
& XA5 & 0.701 & 0.000 & Valid \\
& XA6 & 0.407 & 0.026 & Valid \\
& XA7 & 0.548 & 0.002 & Valid \\
\hline \multirow{3}{*}{ CPA } & XB1 & 0.879 & 0.000 & Valid \\
& XB2 & 0.865 & 0.000 & Valid \\
& XB3 & 0.808 & 0.000 & Valid \\
\hline \multirow{3}{*}{ CPT } & XC1 & 0,908 & 0.000 & Valid \\
& XC2 & 0.939 & 0.000 & Valid \\
& XC3 & 0.923 & 0.000 & Valid \\
\hline & XD1 & 0.664 & 0.000 & Valid \\
& XD2 & 0.832 & 0.000 & Valid \\
& XD3 & 0.827 & 0.000 & Valid \\
\hline & Y1 & 0.865 & 0.000 & Valid \\
& Y2 & 0.835 & 0.000 & Valid \\
& Y3 & 0.872 & 0.000 & Valid \\
& Y4 & 0.895 & 0.000 & Valid \\
& Y5 & 0.860 & 0.000 & Valid \\
\hline
\end{tabular}

The Results of Data Processing Using SPSS.

Based on the table that estimates the value of the Product correlation coefficient moment, the results show that all variables' questions have a $r$ statistic greater than $r$ table $(\mathrm{N}=30$, $\boldsymbol{\alpha}=0.05)$ 0.361. Therefore, the questionnaire can then proceed to the reliability test.

Table 2. Reliability Test Results

\begin{tabular}{ccc}
\hline Variables & Cronbach's Alpha & Conclusion \\
\hline COOI & 0.792 & Reliable \\
CPA & 0.806 & Reliable \\
CPT & 0.911 & Reliable \\
CPE & 0.674 & Reliable \\
PI & 0.916 & Reliable \\
\hline
\end{tabular}

The Results of Data Processing Using SPSS.

Based on the results of the reliability test, it can be seen that the value of all variables' Cronbach Alpha coefficient are greater than 0.6. These reflected that the research instruments are reliable and can be applied to measurements of the sample.

\subsection{Test Assumptions}

The classic assumption test was done by testing normality, heteroscedasticity and multicollinearity. These tests are conducted to meet the requirements so that the equations obtained by multiple linear regression can be accepted. The results revealed that:

- Normality assumption is fulfilled since the skewness and kurtosis values are still in the cut-off point in $\mathrm{z}$ score range of +-1.96 for $95 \%$ confidence interval.

- Since all of the $\mathrm{VIF}<10$ and Tolerance $>0.10$, there is no multicollinearity between independent variables.

- The standardized residual and standardized prediction in the scatterplot is not creating a 
pattern, this means it does pass the homoscedasticity assumption test.

\subsection{Multi Linear Regression}

Table 3. Coefficients ${ }^{a}$

\begin{tabular}{|c|c|c|c|c|c|c|c|}
\hline \multirow{2}{*}{ Model } & \multicolumn{2}{|c|}{$\begin{array}{l}\text { Unstandardized } \\
\text { Coefficients }\end{array}$} & \multirow{2}{*}{$\begin{array}{c}\begin{array}{c}\text { Standardized } \\
\text { Coefficients }\end{array} \\
\text { Beta }\end{array}$} & \multirow[b]{2}{*}{$\mathrm{t}$} & \multirow[b]{2}{*}{ Sig. } & \multicolumn{2}{|c|}{$\begin{array}{c}\text { Collinearity } \\
\text { Statistics }\end{array}$} \\
\hline & B & $\begin{array}{c}\text { Std. } \\
\text { Error }\end{array}$ & & & & Tolerance & VIF \\
\hline 1 (Constant) & 2.597 & 2.184 & & 1.189 & .236 & & \\
\hline $\mathrm{COO}$ & .193 & .080 & .161 & 2.400 & .017 & .748 & 1.336 \\
\hline CPA & -.473 & .168 & -.248 & -2.818 & .005 & .435 & 2.300 \\
\hline $\mathrm{CPT}$ & .705 & .179 & .356 & 3.937 & .000 & .411 & 2.431 \\
\hline CPE & .667 & .221 & .298 & 3.016 & .003 & .345 & 2.902 \\
\hline
\end{tabular}

Based on the table 3, the regression model can be defined as follows:

$Y=0.193 X 1-0.473 X 2+0.705 X 3+0.667 X 4+2.597$

According to the result, it can be concluded that all independent variables, namely country of origin image, celebrity perceived attractiveness, celebrity perceived trustworthiness, and celebrity perceived expertise, significantly influence the purchase intention since all the significance levels are below 0.5 . The constate indicates that if there are no COO, celebrity perceived attractiveness, celebrity perceived trustworthiness, and celebrity perceived expertise variables that affect purchase intention, then purchase intention is 2.597 units.

Furthermore, if the Country of origin image variable increases by one unit, then the purchase intention will increase by 0.193 assuming the other independent variables are fixed. If the Celebrity perceived trustworthiness variable increases by one unit, then the purchase intention will increase by 0.705 assuming the other independent variables are fixed. If the Celebrity perceived expertise variable increases by one unit, then the purchase intention will increase by 0.667 assuming the other independent variables are fixed. However, the relationship between celebrity perceived attractiveness and purchase intention is a negative relationship, where if the Celebrity perceived attractiveness variable increases by one unit, then the purchase intention will decrease 0.473 assuming the other independent variables are fixed.

\subsection{Hypotheses Testing}

- $\quad$ F Test

Table 4. ANOVAa

\begin{tabular}{llccccc}
\hline & Model & Sum of Squares & df & Mean Square & F & Sig. \\
\hline \multirow{2}{*}{1} & Regression & 1385.564 & 4 & 346.391 & & \\
& Residual & 3258.230 & 209 & 15.590 & 22.219 & $\mathbf{. 0 0 0}^{\boldsymbol{b}}$ \\
& Total & 4643.794 & 213 & & \\
\hline
\end{tabular}

a. Dependent Variable: PI 


\section{b. Predictors: (Constant), CPE, COO, CPA, CPT}

The results of Data Processing Using SPSS.

The outcomes of the analysis using multiple linear regression signify that there is a significance value of $0,000(0,009<0.05)$. This value can prove the research hypothesis can be accepted, which implies that "There is a significant effect of country of origin image, celebrity perceived attractiveness, celebrity perceived trustworthiness, and celebrity perceived expertise, simultaneously on the Purchase Intention".

\section{- $\quad$ T Test}

Table 5. Coefficients ${ }^{a}$

\begin{tabular}{|c|c|c|c|c|c|c|c|}
\hline \multirow{2}{*}{ Model } & \multicolumn{2}{|c|}{$\begin{array}{c}\text { Unstandardized } \\
\text { Coefficients }\end{array}$} & \multirow{2}{*}{$\begin{array}{c}\begin{array}{r}\text { Standardized } \\
\text { Coefficients }\end{array} \\
\text { Beta }\end{array}$} & \multirow[b]{2}{*}{$\mathrm{t}$} & \multirow[b]{2}{*}{ Sig. } & \multicolumn{2}{|c|}{$\begin{array}{c}\text { Collinearity } \\
\text { Statistics }\end{array}$} \\
\hline & B & $\begin{array}{l}\text { Std. } \\
\text { Error }\end{array}$ & & & & Tolerance & VIF \\
\hline 2 (Constant) & 2.597 & 2.184 & & 1.189 & .236 & & \\
\hline $\mathrm{COO}$ & .193 & .080 & .161 & 2.400 & .017 & .748 & 1.336 \\
\hline CPA & -.473 & .168 & -.248 & -2.818 & .005 & .435 & 2.300 \\
\hline CPT & .705 & .179 & .356 & 3.937 & .000 & .411 & 2.431 \\
\hline $\mathrm{CPE}$ & .667 & .221 & .298 & 3.016 & .003 & .345 & 2.902 \\
\hline
\end{tabular}

a. Dependent Variable: PI

The Results of Data Processing Using SPSS.

The results of multiple linear regression analysis test indicate that:

- The significance value of Country of origin image towards purchase intention is 0.017 $(0.017<0.05)$. This value can prove the hypothesis is accepted, which means that "There is a significant Effect of Country of origin image on Purchase Intention". Furthermore, the regression coefficient value is 0.193 that means country of origin image gives a positive effect on purchase intention.

- The significance value of Celebrity perceived attractiveness towards purchase intention is $0.005(0.005<0.05)$. This value can prove the hypothesis is accepted, which means that "There is a significant Effect of Celebrity perceived attractiveness on Purchase Intention". However, the regression coefficient value is $(-0.473)$ that means celebrity perceived attractiveness gives a negative effect on purchase intention.

- The significance value of Celebrity perceived trustworthiness towards purchase intention is $0.000(0.000<0.05)$. This value can prove the hypothesis is accepted, which means that "There is a significant Effect of Celebrity perceived trustworthiness on Purchase Intention". Furthermore, the regression coefficient value is 0.705 that means celebrity perceived trustworthiness gives a positive effect on purchase intention.

- The significance value of Celebrity perceived expertise towards purchase intention is 0.003 $(0.003<0.05)$. This value can prove the hypothesis is accepted, which means that "There is a significant Effect of Celebrity perceived expertise on Purchase Intention". Furthermore, the regression coefficient value is 0.667 that means celebrity perceived expertise gives a positive effect on purchase intention. 


\section{- Coefficient of Determination}

\begin{tabular}{cccccc}
\multicolumn{7}{c}{ Table 6. Model Summary } \\
\hline Model & $\mathrm{R}$ & $\mathrm{R}$ Square & $\begin{array}{c}\text { Adjusted R } \\
\text { Square }\end{array}$ & $\begin{array}{c}\text { Std. Error of the } \\
\text { Estimate }\end{array}$ & Durbin-Watson \\
\hline 1 & $\mathbf{. 5 4 6}^{\boldsymbol{a}}$ & .298 & .285 & 3.94837 & 1.810 \\
\hline
\end{tabular}

a. Predictors: (Constant), CPE, COO, CPA, CPT

b. Dependent Variable: PI

The Results of Data Processing Using SPSS.

The R Square value is 0.298 that means $29.8 \%$ of the total variation of purchase intention is explained by the regression model consisting of country of origin image, celebrity perceived attractiveness, celebrity perceived trustworthiness, and celebrity perceived expertise. The other $70.2 \%$ of total variation is explained by other factors.

\subsection{Discussion}

According to the hypotheses testing, there is a significant and positive influence of country of origin image on purchase intention. This result is in line with the study undertaken by Hien et al. [11] stated that Country of origin image provides a significant information in evaluating the brand of the product, specifically COO image is influencing customer's purchase intention positively. This result also supports, Hanzaee \& Khosrozadeh [10] indicated that $\mathrm{COO}$ image has a significant effect on purchase intention of consumers and Kim et al. [8] who explained that a stronger country of origin image of will result in higher purchase intention of consumers.

Regarding the influence of the three dimensions of celebrity perceived credibility on purchase intention of Skechers brand in Indonesia. This study reveals that there are positive and significant impact of celebrity perceived expertise and celebrity perceived trustworthiness on purchase intention, celebrity perceived attractiveness also has a significant relationship with purchase intention yet the influence is negative.

Therefore, two of the dimension of celebrity perceived credibility, namely celebrity perceived expertise and trustworthiness who have positive and significant effect on purchase intention, are in line with the study of Pornpitakpan [5], who indicated that celebrity perceived attractiveness, celebrity perceived trustworthiness, and celebrity perceived expertise are positively and significantly influence the purchase intention of Singaporean, where they seem prioritise the celebrities' perceived attractiveness and celebrities' perceived trustworthiness. While, in this study, celebrity perceived attractiveness has negative and significant influence on purchase intention.

According to Ohanian [12], an influencer that has been perceived as an expert tends to be more persuasive and able to drive purchase intention of consumers. Furthermore, trustworthy celebrity who provides effective endorsement should reinforce the credibility of the brand image, alleviate negative attitudes against the brand [15][25].

The negative relationship between celebrity perceived attractiveness and purchase intention is in accordance with the study of Hassan and Jamil [26] indicated that attractiveness of celebrity gives negative effect on purchase intention in Pakistan. Hassan and Jamil [26] further implied that the reason behind this negative relationship is because well-known products have strong images in the perspectives of consumers, hence consumers are least concerned about the celebrity attractiveness and most famous products are collaborating with 
well-known personalities as their endorser. So, the purpose of physical outlook is to attract consumers' attention towards Ads, not affecting purchase intention. Another reason is because consumers are conscious about the quality and hold on practical knowledge in deciding any negative or positive behavior towards the products instead of considering the physical appearance of celebrity [26].

Johansson and Bozan [27] suggested that research has revealed that celebrity endorser with an attractive image could decrease the self-esteem of consumers and has a negative influence towards intention to buy. On the other hand, using an unattractive celebrity endorser could conceivably increase the self-esteem of consumers and has a positive impact on intention to buy [28].

\section{Conclusion}

In accordance with the research question, the conclusions that can be taken from this study are:

- There is a positive and significant influence between the country of origin image variable on the purchase intention of Skechers brand in Indonesia, meaning that the greater the Country of Origin image, the greater the purchase intention of customers.

- There is a negative and significant influence between the celebrity perceived attractiveness variable on the purchase intention of Skechers brand in Indonesia, meaning that the greater the celebrity perceived attractiveness, the lower the purchase intention.

- There is a positive and significant influence between the celebrity perceived trustworthiness variable on the purchase intention of Skechers brand in Indonesia, meaning that the greater the celebrity perceived trustworthiness, the greater the purchase intention.

- There is a positive and significant influence between the celebrity perceived expertise variable on the purchase intention of Skechers brand in Indonesia, meaning that the greater the celebrity perceived expertise, the greater the purchase intention.

\subsection{Recommendations}

In practical terms, the suggestions given to Skechers brand management are:

- Skechers should consider to implement and take the advantage of their country of origin image, which is United States, since it significantly and positively influences the customers' purchase intention

- In deciding which celebrity to be collaborated with Skechers, to be their ambassador or endorser, Skechers should examine the perceived expertise and perceived trustworthiness of the celebrity instead of choosing celebrity that is known for their attractiveness.

\section{References}

[1] I. Doole and R. Lowe, "International marketing strategy: analysis, development and implementation," Cengage Learn. EMEA, 2008.

[2] R. Q. Danish, M. K. Khan, M. M. Ghafoor, I. Ahmad, A. A. Humayon, and S. Aslam, "Impact of Brand Loyalty in Assessing Purchase Intentions of a Customer: A Study of Automobile Industry in South Asian Perspective," South Asian Stud., vol. 33, no. 2, p. 347, 2018. 
[3] S. Anwar, S. Yasin, A. Iqbal, and M. Sajid, "Country-of-origin Impact on Brand Perception," Eur. J. Bus. Manag., vol. 5, no. 8, pp. 199-209, 2013.

[4] M. R. Benatti, "The effects of globalization on the fashion industry," Univerisdade de Lisboa, 2016.

[5] C. Pornpitakpan, "The Effect of Celebrity Endorsers' Perceived Credibility on Product Purchase Intention," J. Int. Consum. Mark., vol. 16, no. 2, pp. 55-74, 2004.

[6] K.-C. Wang and T. Ahn, "Which Endorser and Content are most influential in Korean Restaurant Promotions?," Int. J. Hosp. Manag., vol. 33, no. 1, pp. 208-218, 2013.

[7] E. D. Jaffe and I. D. Nebenzahl, National Image \& Competitive Advantage: The Theory and Practice of Place Branding. Denmark: Copenhagen Business School Press, 2006.

[8] E. Kim, N., Chun and E. Ko, "Country of origin effects on brand image, brand evaluation, and purchase intention. A closer look at Seoul, New York, and Paris fashion collection," Int. Mark. Rev., vol. 34, no. 02, pp. 254-271, 2017.

[9] N. Koschate-Fischer, A. Diamantopoulos, and K. Oldenkotte, "Are consumers really willing to pay more for a favorable country image? A study of country-of-origin effects on willingness to pay," J. Int. Mark., vol. 20, no. 1, pp. 19-41, 2012.

[10] K. H. Hanzaee and S. Khosrozadeh, "The Effect of the Country-of-Origin Image, Product Knowledge and Product Involvement on Information Search and Purchase Intention," MiddleEast J. Sci. Res., vol. 8, no. 3, pp. 625-636, 2011.

[11] N. N. Hien, N. N. Phuong, T. V. Tran, and L. D. Thang, "The effect of country-of-origin image on purchase intention: The mediating role of brand image and brand evaluation," Manag. Sci. Lett., vol. 10, no. 6, pp. 1205-1212, 2020.

[12] R. Ohanian, "The impact of celebrity spokespersons' perceived image on consumers' intention to purchase," J. Advert. Res., 1991.

[13] C. Amos, G. Holmes, and D. Strutton, "Exploring The Relationship Between Celebrity Endorser Effects and Advertising Effectiveness: A Quantitative Synthesis of Effect Size," Int. J. Advert., vol. 27, no. 2, pp. 209-234, 2008.

[14] H. H. Friedman, S. Termini, and R. Washington, "The Effectiveness of Advertisements Utilizing Four Types of Endorsers," J. Advert., vol. 5, no. 3, pp. 22-24, 1976.

[15] D. J. Ketchen Jr., L. Adams, Garry, and C. L. Shook, "Understanding and Managing CEO Celebrity," Bus. Horiz., vol. 51, no. 6, pp. 529-534, 2008.

[16] N. J. Rifon, M. Jiang, and S. Kim, "Don't Hate me Because I am Beautiful: Identifying the Relative Influence of Celebrity Attractiveness and Character Traits on Credibility," Adv. Advert. Res., vol. VI, pp. 125-134, 2016.

[17] G. McCracken, "Who is the Celebrity Endorser? Cultural Foundations of the Endorsement Process," J. Consum. Res., vol. 16, no. 3, pp. 310-321, 1989.

[18] R. Ohanian, "Construction and Validation of a Scale to Measure Celebrity Endosers' Perceived Expertise, Trustwothiness, and Attractiveness," J. Advert., vol. 19, no. 3, pp. 39-52, 1990.

[19] K. Osei-Frimpong, G. Donkor, and N. Owusu-Frimpong, "The Impact of Celebrity Endorsement On Consumer Purchase Intention: An Emerging Market Perspective," J. Mark. Theory Pract., vol. 27, no. 1, pp. 103-121, 2019.

[20] J. F. Engel, R. D. Blackwell, and P. W. Miniard, Consumer Behavior. Dryden Press, 1990.

[21] W. B. Dodds, K. B. Monroe, and D. Grewal, "Effects of Price, Brand and Store Information On Buyers' Product Evaluations," J. Mark. Res., vol. 28, no. 3, pp. 307-319, 1991.

[22] D. Sugiyono, Metode penelitian bisnis. Bandung: Pusat Bahasa Depdiknas, 2008.

[23] J. F. ua Hair, Multivariate Data Analysis With Readings. Englewood Cliffs, 1995.

[24] H. Umar, Metode riset bisnis: panduan mahasiswa untuk melaksanakan riset dilengkapi contoh proposal dan hasil riset bidang manajemen dan akuntansi. Gramedia Pustaka Utama, 2002.

[25] P. Gilchrist, "Local Heroes or Global Stars," in Global Politics of Sport, L. Allison, Ed. UK: Routledge, 2005, pp. 118-139.

[26] R. A. Jamil and S. Rameez ul Hassan, "Influence of celebrity endorsement on consumer purchase intention for existing products: a comparative study," J. Manag. Info, vol. 4, no. 1, pp. $1-23,2014$. 
[27] M. Johansson and Ö. Bozan, "How does celebrity endorsement affect consumers' perception on brand image and purchase intention?," 2017.

[28] M. Sääksjärvi, K. Hellén, and G. Balabanis, "Sometimes a Celebrity Holding a Negative Public Image is the Best Product Endorser," Eur. J. Mark., vol. 50, 2016. 